Plant molecular biology 21: 413, 1993.

(C) 1993 Kluwer Academic Publishers. Printed in Belgium.

Erratum

\title{
The psbl gene from bell pepper (Capsicum annuum): plastid RNA editing also occurs in non-photosynthetic chromoplasts
}

\author{
Marcel Kuntz ${ }^{1}$, Bilal Camara ${ }^{2}$, Jacques-Henry Weil ${ }^{1}$ and Rodolphe Schantz ${ }^{1}$ \\ ${ }^{1}$ Insitut de Biologie Moléculaire des Plantes du C.N.R.S., Université Louis Pasteur, 12 Rue du Général \\ Zimmer, 67084 Strasbourg, France; ${ }^{2}$ Université de Bordeaux 1, Biochimie et Régulation Cellulaire, Avenue \\ des Facultés, 33405 Talence, France \\ Plant Molecular Biology 20: 1185-1188, 1992. \\ On page 1187 of this paper, in the first column, the first line should read: \\ "and poly(A) ${ }^{-}$RNA isolated from bell pepper leaves".

\section{Erratum}

In Plant Molecular Biology, Volume 20, issue no. $4,{ }^{*}$ the title of the News and Views article on page 575, should read:

"Organization, instability and evolution of plant disease resistance genes".

The title of the News and Views article on page 578 should read:

"Extramarital sex amongst the beets - Evidence for gene exchanges between sugar beet (Beta vulgaris $\mathbf{L}$.) and wild beets: consequences for transgenic sugar beets."

Erratum

\section{Expression of a chimeric CaMV 35S Bacillus thuringiensis insecticidal protein gene in transgenic tobacco}

Nadine B. Carozzi, Gregory W. Warren, Nalini Desai, Susan M. Jayne, Richard Lotstein, Douglas A. Rice, Stephen Evola and Michael G. Koziel CIBA-Geigy Agricultural Biotechnology Research Unit, 3054 Cornwallis Road, Research Triangle Park, $N C 27709, U S A$

Plant Molecular Biology 20: 539-548, 1992.

The title in reference 27 shoud read:

"Field evaluation of transgenic tobacco containing a Bacillus thuringensis insecticidal protein gene. J. Econ. Entom 85: 1651-1659 (1992).

\footnotetext{
* The titles of two papers have been partly interchanged.
} 